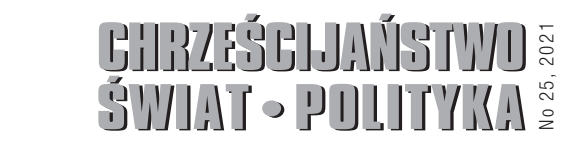

ZESZYTY SPOŁECZNEJ MYŚLI KOŚCIOŁA

\title{
Sławomir Sowiński
}

Uniwersytet Kardynała Stefana Wyszyńskiego w Warszawie, Polska

ORCID: 0000-0003-1324-121X

\section{Twórcze napięcie między religia a polityka i espistemologiczne pokusy jego redukcji na gruncie nauk o polityce}

\author{
Pamięci prof. Ernsta-Wolfganga Böckenfördego
}

\begin{abstract}
Abstrakt. Słynny „paradoks Böckenfördego” może prowadzić do pytania: czy współczesne nauki o polityce potrafią uchwycić wartość strukturalnego napięcie między religią a polityką? I w polityce, i w świecie religii dostrzec można tendencję do redukcji tego napięcia, albo poprzez próbę utożsamiania polityki z religią, albo poprzez ich całkowite separowanie. W wymiarze epistemologicznego tendencję do redukcji tego napięcia dostrzec można także w naukach o polityce, choć w różnych stopniu występuje ono w ujęciach: funkcjonalistycznym, instytucjonalnym, czy historycznym.
\end{abstract}

Słowa kluczowe: Böckenförde, polityka, politologia religii, religia

\begin{abstract}
The „Böckenförde paradox” may lead to the question: of modern political science can capture the value of the structural tension between religion and politics? In politics and the world of religion too, there is a tendency to reduce this tension, either by trying to identify politics with religion, or by completely separating them. In the epistemological dimension, the tendency to reduce this tension can also be seen in the sciences of politics, although it occurs to a different extent in functionalistic, institutional or historical approaches.
\end{abstract}

Keywords: Böckenförde, politics, political science of religion, religion

Zmarły niedawno wybitny niemiecki prawnik i konstytucjonalista profesor ErnstWolfgang Böckenförde utwierdzał nasze przekonanie, że wzajemne relacje między religią a polityką, pomimo ich długowieczności i przeróżnych doświadczeń, także 
dziś w epoce postsekularnej, mają ciągle żywy, dynamiczny i otwarty charakter, naznaczony nierozstrzygniętymi i nierozstrzygalnymi być może do końca dylematami. Do takiej właśnie konstatacji prowadzić może choćby słynny „paradoks Böckenfördego", zgodnie z którym wolnościowe demokratyczne państwo prawa korzystać musi z aksjologicznych źródeł, których wytworzyć samo nie może ${ }^{1}$, czy inna jego trafna uwaga o tym, że w systemie demokratycznym Kościoły wybierać mogą między misją polityczną a metapolityczną, nie mogąc jednak wiarygodnie pełnić ich równocześnie².

Warto jednak zastanowić się czy współczesne nauki społeczne, a szczególnie nauki o polityce, od dawna już zgłaszające swe ambicje do wyjaśniania - przynajmniej z punktu widzenia polityki - charakteru oraz znaczenia tych relacji, posiadają ku temu odpowiednie kompetencje oraz instrumentarium metodologiczne. Interesujące wydaje się w tym kontekście zwłaszcza pytanie, czy współczesne nauki o polityce są $\mathrm{w}$ stanie dostrzec i właściwie ocenić szczególne napięcie jakie rodzi się między religią a polityką? Czy też, z powodów metodologicznych lub aksjologicznych, tkwi w nich naturalna skłonność do epistemologicznej - by tak rzec - redukcji tego napięcia?

Temu właśnie zagadnieniu chcemy poświęcić nasze rozważania.

${ }^{1}$ Sam prof. Böckenförde paradoks ten formułował tak: „liberalne, zsekularyzowane państwo ma podstawę w czymś, czego samo nie może zagwarantować. Tu tkwi wielkie ryzyko, które państwo wzięło na siebie chcąc podjąć i sprostać wyzwaniu wolności. Państwo może istnieć jako państwo liberalne tylko dzięki temu, że wolność którą zapewnia obywatelom będzie regulowana od wewnątrz, z racji moralnej substancji jednostki i jedności społeczeństwa" [Böckenförde 1994: 120].

2 Jak podkreśla prof. Böckenförde, jeden i drugi wybór (roli politycznej lub metapolitycznej) Kościoła, z punktu widzenia reguł demokratycznego państwa jest możliwy. Jednego jednak Kościół - bez utraty wiarygodności - uczynić nie może, nie może łączyć obu strategii i „korzystać z demokracji dopóki osiąga większość, a w przypadku porażki wycofać się na pozycję prawa naturalnego i wskazywać na swą wyjątkową pozycję" [tamże:42]. Co ciekawe, świadomość ta zakorzeniła się także w nauczaniu społecznym Kościoła katolickiego w Polsce. Przewodniczący Konferencji Episkopatu Polski ks. abp Stanisław Gądecki, swą uroczystą homilię wygłoszoną podczas Mszy św. w 100 rocznicę odzyskania przez Polskę niepodległości podsumowywał między innymi następującym stwierdzeniem: „Kościół (...), ma obowiązek przemawiać z pozycji metapolitycznych, przypominając o normach, zasadach i wartościach etycznych, jakimi powinien kierować się rząd podejmując decyzje w tej dziedzinie. Nie może jednak - jeśli nie chce utracić swojej politycznej wiarygodności - zmieniać formy swego zaangażowania z politycznej na metapolityczną i odwrotnie, w zależności od tego, co w danym momencie uzna za bardziej dla siebie korzystne" [BP KEP 2018]. 
Aby je sensownie podjąć, na wstępie zarysujemy charakter oraz polityczną wartość owego szczególnego napięcia jakie rodzi się między religią a polityką (pkt.1), a także różne tendencje czy też pokusy jego redukcji jakie dochodzą do głosu na poziomie politycznej praktyki (pkt. 2). W zasadniczej jednak części naszych rozważań zastanowić się chcemy, na ile (pkt. 3) i w jakiej formie (pkt. 4 i 5) owa redukcja dochodzić może do głosu nie tyle w wymiarze politycznej praktyki, co w espistemologicznym wymiarze analizy procesu politycznego. Chcemy też zastanowić się, w jakim zakresie tendencję owej epistemologicznej redukcji niosą niektóre, obecne w naukach o polityce, ich ujęcia teoretyczne, a więc funkcjonalizm, instytucjonalizm czy ujęcie historyczne (pkt. 6).

\section{Napięcie między religią a polityką $i$ jego wartość}

Oczywiście nie tylko Ernst-Wolfgang Böckenförde zwracał uwagę, że demokratyczna polityka i religia (a w każdym razie interesujące nas tu chrześcijaństwo) pozostają i pozostawać powinny w stanie swoistego niedopasowania, niekończącego się dialogu, który w jakimś wymiarze pozostaje także sporem.

Taki kształt tej relacji niesie też ze sobą formuła „autonomii i współpracy” Kościoła i państwa obecna bardzo wyraźnie w społecznym nauczaniu Kościoła katolickiego i katolickiej nauce społecznej, co najmniej od Soboru Watykańskiego II. W ujęciu tym podkreśla się, że niezależne od siebie Kościół i państwo, zachowując swą odrębność, oraz respektując wolność religijną (wierzących oraz i niewierzących) obywateli, powinny współdziałać dla dobra wspólnego ${ }^{3}$. Religia zaś, dystansując się od bezpośredniego procesu politycznego (ale broniąc się także przez próbami jej prywatyzacji) chronić powinna swój status publiczny i metapolityczny, dzięki któremu pośrednio wpływać może także na jakość procesu politycznego [Sowiński 2012]. Rozwijając tę perspektywę Piotr Mazurkiewicz rozważa w tym

3 Taką właśnie formułę odnaleźć można między innymi w nauczaniu Soboru Watykańskiego II, ale także - co ciekawe - w polskiej Konstytucji z roku 1997. „Konstytucja duszpasterska o Kościele w świecie współczesnym” Soboru Watykańskiego II (Gaudium et Spes) stwierdza: „Wspólnota polityczna i Kościół są w swoich dziedzinach niezależne i autonomiczne. Obydwie jednak wspólnoty, choć z różnego tytułu, służą powołaniu jednostkowemu i społecznemu tych samych ludzi. Tym skuteczniej będą wykonywać tę służbę dla dobra wszystkich, im lepiej będą rozwijać między sobą zdrową współpracę uwzględniając także okoliczności miejsca i czasu" [Konstytucja duszpasterska o Kościele w świece współczesnym: 604]. Z kolei w art 25 pkt. 3 Konstytucji Rzeczpospolitej Polskiej z 2 kwietnia 1997 stanowi, że "Stosunki między państwem a Kościołami i innymi związkami wyznaniowymi są kształtowane na zasadach poszanowania ich autonomii oraz wzajemnej niezależności każdego w swoim zakresie, jak również współdziałania dla dobra człowieka i dobra wspólnego" [Konstytucja Rzeczpospolitej Polskiej]. 
kontekście znaczenie postulatu „niepolitycznej polityczności Kościoła”, Aniela Dylus wskazuje na niepowtarzalną, specyficzną rolę Kościoła w społeczeństwie demokratycznym ${ }^{5}$, o. Maciej Zięba zwraca uwagę na niebezpieczeństwa ideologizacji religii i agnostycyzmu religijnego [Zięba 1998: 94]. Piotr Burgoński opisuje model „obecności i naturalnego napięcia” Kościoła w polskiej sferze publicznej [Burgoński 2013: 23] a piszący te słowa analizuje wątek „obecność, odmienności, transcendencji” Kościoła w sferze publicznej, który dystansuje się zarówno od prób jego upolitycznienia jak i prywatyzacji [Sowiński 2012: 333-345].

Intuicja, że religie we współczesnej demokracji szukać powinny swej publicznej ścieżki między próbą ich prywatyzacji, a pokusą wciągania do gry politycznej ma oczywiście charakter znaczniej bardziej uniwersalny, niż tylko nauczanie społeczne Kościoła katolickiego. We współczesnej myśli filozoficznej i społecznej szukać jej można co najmniej od czasów de Tocqueville’a [1996] czy lorda Actona [1995] po refleksję takich choćby współczesnych wybitnych myślicieli jak Jürgen Habermas [Teinert 2006], José Casanova [2005] czy Leszek Kołakowski [1990].

Dalej jednak myśli tej nie rozwijając, ogólnie stwierdzić możemy, że w relacjonowanym tu - i dość szeroko podzielanym dziś chyba - przekonaniu religia (a na pewno współczesne chrześcijaństwo) i współczesna demokratyczna polityka, dla dobra obu, wzajemnie sobie towarzysząc, zachowywać powinny jednocześnie własną odmienność i autonomię. Ujmując rzecz krótko, mówimy tu zatem o modelu swego rodzaju napięcia między religią a polityką, które - analogicznie jak w układach fizycznych czy biologicznych - rodzi się na skutek regularnie oddziałujących na siebie różnorodności. Napięcia, które prowadząc do nieuchronnych

${ }^{4}$ Jak podkreśla ten wytrawny badacz relacji między religią a polityką, Kościół katolicki mobilizując swych wiernych (i wszystkich ludzi dobrej woli) do publicznego zaangażowania, solidarności i odpowiedzialności podkreślana jednocześnie swoją odmienną od państwa tożsamość. Pisze on, „Chrześcijaństwo, z jednej strony, podkreśla etyczny wymiar politycznego zaangażowania, mobilizując wiernych do podejmowania politycznej odpowiedzialności; z drugiej za zaś, przypomina o niezbywalności w tym świecie Kościoła, jako instytucji radyklanie odmiennej od państwa" [Mazurkiewicz 2017: 252-253].

5 Analizując różne modele relacji Kościół-państwo autorka, dystansuje się wobec modelu Kościoła „państwowego”, „mieszającego się do polityki”, „dekretującego prawdę”, „grupy interesu”, przypominającego stowarzyszenie Kościoła „horyzontalnego”, Kościoła „zdemokratyzowanego”, czy „Kościoła radykalnie oddzielonego od państwa”. Opowiada się natomiast za modelem „wolnego Kościoła w wolnym państwie”, „umiarkowanie oddzielonego od państwa”, Kościoła, który wprawdzie nie unika „zaangażowania społecznego” czy podejmowania - w sytuacjach szczególnych - „funkcji zastępczych”, ale w demokratycznym państwie, chce być „solą ziemi” i „Kościołem mistycznym” (Określenia w cudzysłowach pochodzą z typologii stworzonej przez autorkę [Dylus 2016: 415-434]. 
kolizji, tarć, nacisków czy naprężeń, wytwarza jednocześnie energię, która służyć może obydwu fenomenom, tego szczególnego układu.

I to właśnie owo szczególne napięcie, jego poziom, charakter, lub jego brak, pozostaje głównym - w gruncie rzeczy - obiektem rzeczowego zainteresowania nauk o polityce próbujących (w perspektywie tego co politycznie) zgłębić i wyjaśnić specyfikę relacji między religią a polityką, a zwłaszcza wpływ religii na życie publiczne, a poprzez to pośrednio, także na proces polityczny.

Bo właśnie dzięki temu napięciu, w sytuacji naturalnego demokratycznego konfliktu politycznego, pełniąc funkcję wspólnototwórcza religia budować i odtwarzać może - niezbędne politycznie - ramy demokratycznej wspólnoty. To dzięki temu napięciu, religia może pełnić wobec procesu politycznego także funkcję korygująca, poprzez nieustanne przywoływanie ludzkiej godności, wolności, solidarności, czy długofalowej odpowiedzialności wobec przyszłych pokoleń. Wreszcie dzięki temu napięciu, także w sytuacji społeczeństwa pluralistycznego, obecna publicznie (choć autonomiczna politycznie) religia, pełnić może przekonująco swego rodzaju funkcję krytyczna, przypominając wiarygodnie, z właściwym sobie eschatologicznym realizmem, o naturalnych ograniczeniach i niedoskonałościach każdego politycznego działania i realny niebezpieczeństwie ideologizacji polityki [Sowiński 2012: 333-345].

Napięcie, o którym tu mówimy, a właściwie sposób jego regulowania wydaje się też tkwić u podstaw - coraz częściej badanej dziś przez politologów - różnorodności politycznych relacji między Kościołami a państwami w Unii Europejskiej. Widać to w perspektywie tzw. „klauzuli kościelnej” (art. 17 Traktatu Lizbońskiego), która chroni dość różne formy takich relacji, zgodne z tradycją i historią poszczególnych państw. W praktyce oznacza to jednoczesne uznanie i respektowanie: rozwiązań francuskich, które od czasów słynnej ustawy z roku 1905, w duchu laïcité religię traktują jako sprawę prywatną obywateli; modeli duńskiego czy greckiego, gdzie największe Kościoły mają de facto charakter państwowy; czy modeli niemieckiego, włoskiego, hiszpańskiego lub polskiego, w których autonomia i współpraca państwa i Kościołów wiąże się ze znaczeniem historycznym i kulturowym religii, a Kościoły pełnią szereg istotnych funkcji społecznych ${ }^{6}$.

${ }^{6}$ Dobrym kompendium omawiającym różne modele relacji państwo Kościół w Unii Europejskiej jest zbiorowa praca pod redakcją profesora Gerharda Robbersa, która po polsku ukazała się pod tytułem Państwo i Kościół w krajach Unii Europejskiej [Robbers 2007]. 
Last but not least zauważmy wreszcie, że brak napięcia, o którym tu mówmy otwiera drogę do - śledzonych dziś uważnie nie tylko w naukach o polityce - wyzwań lub niebezpieczeństw takich jak religijny lub świecki fundamentalizm, ideologizacja lub polityczne instrumentalizacja religii [Grosfeld 2009; Gierycz 2009], „etnizacja religii” [Zenderowski 2011] czy „sakralizacja etnosu” [tamże].

\section{Tendencje do redukcji napięcia między religią a polityką. Wymiar polityczny}

Ostatnia nasza uwaga przywołuje równie istotną w perspektywie nauk o polityce kwestię jaką jest naturalna (w jakimś sensie) polityczna pokusa, czy też tendencja do redukowania opisywanego tu przez nas napięcia.

Konstatując i podkreślając wartość jaką niesie ze sobą owo strukturalne napięcie między religią a polityką trzeba bowiem pamiętać, że napięcie to, tak jak każde napięcie, oddziałując na połączone nim elementy czy fenomeny, wywiera nacisk na ich wewnętrzne procesy i struktury. W sytuacji zaś gdy nacisk ten jest szczególnie odczuwalny, fenomen jakim jest układ polityczny może (od)reagować dążeniem do takiej lub innej formy rozładowania lub redukcji owego napięcia. Przekładając to na interesujący nas tu przede wszystkim wymiar polityczny zauważyć możemy, że strukturalne napięcie między religią a polityką rodzić może polityczną obawę nie tylko o trwały konflikt między państwem a Kościołami (czy związkami wyznaniowymi), ale także o funkcjonalność układu politycznego, a przede wszystkim o polityczną suwerenność jego władzy. Stąd też często spotykaną tendencją, i tradycyjnych i współczesnych systemów politycznych (a zwłaszcza ich władzy), jest dążenie do częściowej redukcji lub całkowitego rozładowania wskazywanego przez nas napięcia.

Takie polityczne tendencje mogą mieć zarówno różny charakter jak i różny zasięg. Odnosząc się do różnorodności ich charakteru ogólnie powiedzieć możemy, że przywoływane przez nas napięcie na sposób polityczny redukować można: albo poprzez próbę ostrej separacji religii od polityki, zmierzającą de facto w stronę prywatyzacji religii, albo poprzez utożsamianie religii z polityką czyli dążenie do ich zwarcia. Jednym z bardziej znanych przykładów - prywatyzującej de facto religię - separacji wydaje się słynna francuska ustawa z grudnia roku 1905, ostro rozdzielająca w III Republice państwo od Kościoła [Basdevant-Gaudemet 2007: 126-127]. Z kolei licznych prób utożsamiania lub wręcz zwierania religii z polityką szukać można w tak różnych okolicznościach i konceptach jak: starożytne formy 
sakralizacji władzy ${ }^{7}$ lub teokracji ${ }^{8}$, pokój Augsburski z roku 1555 r. (z jego naczelną zasadą „cuius regio eius religio”), czy różne odmiany tzw. religii obywatelskich?.

I choć obie wskazane tu polityczne tendencje (separacja i utożsamianie) zdają się zmierzać w przeciwnych zupełnie kierunkach (radykalnej świeckości władzy lub rządów [quasi] teokratycznych), to $\mathrm{z}$ interesującego nas tu punktu widzenia, ich skutek jest podobny. A jest nim właśnie redukcja napięcia między religią a polityką, co w konsekwencji oznacza na ogół zdominowanie specyficznej misji religii przez ambicje czy cele polityczne. W obu przypadkach rodzić się mogą podobne skutki polegające na ograniczaniu czy wręcz niwelowaniu, wymienionego wyżej, metapolitycznego, wspólnototwórczego, krytycznego i korygującego wkładu religii w proces polityczny. $\mathrm{W}$ obu też przypadkach zwiększać się może ryzyko rodzenia się fundamentalizmów, w pierwszym świeckiego, w drugim religijnego.

Odnosząc się jeszcze do podniesionej wyżej kwestii drugiej, a więc możliwego zasięgu takich politycznych działań, równie ogólnie zauważyć możemy, że zarówno próby separacji jak i utożsamiania religii i polityki, przybierać mogą albo wymiar bardziej strukturalny, polegający na odpowiednich rozwiązaniach instytucjonalnych $^{10}$, wpisanych w same podstawy systemu politycznego, albo wymiar bardziej

7 Wybitny znawca katolickiej nauki społecznej kard. Josef Höffner, jako przykład wymienia w tym kontekście między innymi kult syryjskiego króla Antiocha, przejawy kultu niektórych cesarzy rzymskich (Augusta, Domicjana, Aureliana, Dioklecjana), czy kult cesarza Inków [Höffner 1999: 240].

8 Przejawy teokratyzmu dostrzega z kolei kard. Höffner na przykład w myśli politycznej partii Zelotów działającej w Izraelu za czasów Chrystusa czy koncepcjach, niektórych teologów średniowiecza. Choć jak podkreśla, próżno szukać ich w myśli czołowych chrześcijańskich myślicieli tej epoki, na przykład u św. Tomasza, czy już w XVI w. u Francisco de Vitorii [tamże: 240-241].

9 Warto przypomnieć, że intelektualne i praktyczne poszukiwania religii obywatelskiej trwają co najmniej od czasów Jeana Jacques’a Rousseau. I choć zarówno badaczy jak i wyznawców tego konceptu zawiodły one w dość różne (i odległe od siebie strony), to do jego istoty należy chyba chęć redukcji napięcia między lojalnością obywatelską a lojalnością strice religijną. Zarówno bowiem świecki koncept religii obywatelskiej, bliższy zapewne duchowi republikanizmu francuskiego, jak i koncepty odwołujące się tradycyjnych religii eschatologicznych, bliższe republikanizmowi amerykańskich „Ojców założycieli”, w swej istocie ograniczać chcą napięcie na jakie narażeni są obywatele żyjący jednocześnie w dwu różnych, niedopasowanych do końca światach, i miłujący jednocześnie, dwie różne ojczyzny. Obywatele lojalni jednocześnie wobec państwa Bożego i państwa ziemskiego [Węgrzecki 2016].

10 Jako pewne przykłady takiego waśnie strukturalnego czy też ustrojowego redukowania napięcia między religią a polityką wskazać można, z jednej strony przywołany już model francuskiej separacji, z drugiej zaś, model kościoła państwowego, w którym - tak jak na przykład w Gracji czy Danii - konstytucja wskazuje jeden Kościół, szczególnie wspierany przez państwo. Przy wszystkich wątpliwościach i dyskusjach jakie budzić mogą te 
taktyczny, polegający na bieżącej polityce jaką ta lub inna władza prowadzić może wobec tego lub innego podmiotu religijnego, podmiot ten politycznie instrumentalizując lub dezawuując $c^{11}$, niezależnie, a czasem wbrew regułom wolności religijnej, jakie wpisane są w działanie demokratycznego systemu politycznego.

\section{Tendencje do redukcji napięcia między religią a polityką. Wymiar epistemologiczny (politologiczny)}

Przypomniane przez nas polityczne tendencje do redukowania napięcia między religią a polityką, a także ich możliwe polityczne konsekwencje, nie są rzecz jasna we współczesnej polityce niczym nowym i jako takie, jak wskazaliśmy wyżej, w tej lub innej formie, spotkały się już na gruncie nauk o polityce ze sporym, także krytycznym, zainteresowaniem. Zdecydowanie mniej natomiast obecny w refleksji naukowej wydaje się epistemologiczny, a nie czysto polityczny, wymiar tego zagadnienia. A owo szczególne napięcie między religią a polityką kłopotem bywa nie tylko dla polityków ale także dla współczesnych politologów.

Z grubsza, problem ten polega na tym, że uzbrojony w swe teoretyczne narzędzia politolog, spotykając na swej naukowej drodze (w sąsiedztwie polityki) fenomen religii, albo uznać może, że religia jako fakt pozapolityczny naukowo interesować go nie może, albo na potrzeby swoich badań uznać może religię za fenomen pod pewnym względem analogiczny do innych fenomenów okołopolitycznych, czy też wręcz politycznych. W przypadku pierwszym, z horyzontu badawczego religia i jej znaczenie znika w ogóle. W przypadku drugim, wprawdzie w horyzoncie tym religia pozostaje, ale już nie jako fenomen szczególnego eschatologicznego rodzaju, ale jako fakt społeczny, publiczny, czy okołopolityczny. W jednym i drugim przypadku dojść może do zapoznania szczególnej roli religii w życiu publicznym (i pośrednio politycznym), a w konsekwencji, do zignorowania przywoływanego tu przez nas napięcia między religią a polityką, a tym samym także, do pominięcia problemu jego redukcji, i wynikających z niego konsekwencji politycznych. A więc kwestii - jak staraliśmy się wykazać wyżej - dla nauk o polityce zgoła niebanalnych.

rozwiązania, oba choć, w zupełnie różny sposób, rozstrzygają wiele praktycznych pytań i wątpliwości dotyczących relacji między państwem a Kościołem, redukując tym samym wskazane przez nas napięcie. Choć w obu tych przypadkach - co warto wyakcentować podkreśla się znaczenie wolności religijnej [Robbers 2007].

11 Bardzo ciekawie w odniesieniu do sytuacji współczesnej Polski pisze o tym m.in. prof. Michał Gierycz [2009]. 
Mówiąc krótko, metodologiczny problem, na który tu wskazujemy polega z na tym, że nawet jeśli napięcie między religią a polityką realnie występuje i oddziałuje na proces polityczny, lub następuje (ze wszystkimi tego konsekwencjami) jego redukcja, to pilnujący swego naukowego warsztatu politolog, czasem może go nie docenić, a czasem w ogóle nie dostrzec.

Koncentrując się zatem w dalszej części naszych rozważań głównie na tym ważnym - jak wolno sądzić - espistemologicznym i metodologicznym zagadnieniu, po pierwsze, spróbujemy się przyjrzeć mu bliżej, śledząc różne jego możliwe warianty. Po wtóre, zastanowimy się nad możliwością jego występowania na gruncie kliku różnych, dominujących w naukach o polityce podejść teoretycznych. Po trzecie wreszcie, bardzo ostrożnie spróbujemy zarysować kilka rekomendacji, które ów epistemologiczny problem na gruncie nauk o polityce pomogłyby ograniczyć.

\section{Redukcja epistemologiczna - wariant separacji}

Redukcja epistemologiczna o której tu mówimy, podobnie jak w przypadku redukcji politycznej, na gruncie nauk o polityce może - jak zauważyliśmy już wyżej - przyjąć dwie główne formy: separacji lub podstawienia.

Redukcja poprzez separację oznacza tu usuwanie religii (i jej wpływu na procesy polityczne) poza obszar poważnej refleksji naukowej dotyczącej domeny spraw politycznych. Jakieś jej przejawy zrodzić się mogą choćby na gruncie głośnych w swoim czasie - bardziej jednak socjologicznych niż politologicznych - koncepcji sekularyzacyjnych Petera Ludwika Bergera [Berger 1997; Borowik 1997], Thomasa Luckmanna [2006], czy Niklasa Luhmanna [2007]. Choć pod różnymi względami zapewne od siebie one się różnią, akcentując bardziej: albo „wyzwalanie się" (w ich ocenie) modernizującego się świata spod wpływu religii (Berger), albo "prywatyzację" religii w nowoczesnym świecie (Luckmann i Luhmann), to wspólną wynikającą z nich konsekwencją badawczą, może być wniosek, że religia nie jest dziś ważnym i znaczącym elementem, w życiu publicznym nowoczesnego społeczeństwa. Innym przykładem takiej właśnie możliwej separujacej redukcji, może być nazbyt uproszczone i jednostronne traktowanie popularnej dziś Popperowskiej koncepcji „społeczeństwa otwartego”. Zwłaszcza takie jej odczytanie, które wszelką tradycyjną aksjologię, a w tym i przekonania religijne, usuwa poza granicę tego racjonalne, a więc poza nawias to, co współczesna nauka może sensownie i krytycznie badać. O niebezpiecznych złudzeniach wynikających z takiego właśnie interpretowania myśli Poppera pisali między innymi, Leszek Kołakowski [1990: 150-177] czy o. Maciej Zięba [2011]. 
Poprzestając na dwóch tylko przykładach takiej możliwej redukcji, ostrożnie możemy jednak założyć, że we współczesnych naukach o polityce, a zwłaszcza wśród badaczy religii i polityki, nie jest ona spotykana zbyt często. Po pierwsze oczywiście dlatego, że badacze związków religii z polityką o obecności tej pierwszej muszą być przekonani niejako z definicji. Po drugie także dlatego, że nawet politolog nie zajmujący się na co dzień związkami religii z polityką, bez uwzględnienia obecności i znaczenia tej pierwszej, będzie miał spory kłopot z sensownym wyjaśnieniem wielu kluczowych współczesnych politycznych procesów, takich jak na przykład: „III fala demokratyzacji”, pokojowe rewolucje w Europie w roku 1989, czy akcesja Polski do Unii Europejskiej w latach 1997-2004.

Sprawą interesującą i wartą oddzielnego namysłu jest pytanie o możliwe przyczyny przywołanej tu redukcji epistemologicznej. Wiele bowiem wskazuje na to, że obok wspomnianego już wyżej kłopotu czysto warsztatowego politologa, który badać ma "niepolityczną polityczność” religii, w grę wchodzić mogą także uwarunkowania szersze, rzecz by można ideowe (czy też ideologiczne). Wątku tego nie rozwijając wspomnijmy tylko, że możne chodzić tu o generalny problem współczesnych nauk społecznych związany z nieufnym traktowaniem przez nie transcendencji [Wysocki 2015], czy nawet szerzej, o szczególną spuściznę oświecenia, którą jest redefinicja, lub też redukcja pojęcia racjonalności, wyłącznie do wymiaru wiedzy empirycznej, weryfikowanej na drodze eksperymentów [Ratzinger 2005].

\section{Redukcja epistemologiczna - wariant podstawienia. Kościół jako grupa interesu? społeczeństwo obywatelskie? III sektor? aktor sfery publicznej?}

Problem epistemologicznej redukcji, o której tu mówimy, na gruncie nauk o polityce występuje także w formie analogii, czy też swego rodzaju teoretycznego podstawienia. Owo podstawienie - jak wspominaliśmy już wyżej - oznacza traktowanie w badaniach naukowych podmiotów religijnych jako jeszcze jednej, szczególnej być może, odmiany szerszego gatunku aktorów okołopolitycznych, którymi politologia zwykła zajmować się na co dzień.

$\mathrm{W}$ wariancie bardziej radykalnym, ale zdecydowanie rzadszym ten rodzaj redukcji występuję tam i wtedy, gdy badacze lub analitycy życia politycznego, z różnych znanym im powodów, traktują Kościoły lub związki wyznaniowe jako uczestniczących $\mathrm{w}$ walce o władzę aktorów procesu politycznego, i to nawet wbrew 
autodeklaracjom samych zainteresowanych ${ }^{12}$. Zdecydowanie częściej redukcja, o której tu mówimy, na gruncie nauk o polityce występuje w formie subtelniejszej, gdy badacze procesu politycznego, zdając sobie sprawę z niepolityczności podmiotów religijnych, sytuują je w obszarze okołopolitycznym, traktując je na przykład jako: szczególny rodzaj grup interesu, część społeczeństwa obywatelskiego, działające w III sektorze instytucje pozarządowe, czy innych aktorów sfery publicznej.

Każda próba takich epistemologicznych analogii czy podstawień ma rzecz jasna swoje merytoryczne racje i świadczy na ogół o dobrej samoświadomości i wysiłku intelektualnym, badaczy, którzy usiłują znaleźć wąską teoretyczną ścieżkę, między respektem dla „niepolityczności” aktorów religijnych, a wiernością swojemu politologicznemu warsztatowi, który nakazuje stosowanie sprawdzonych podejść teoretycznych i metod badawczych. Każdy z tych badawczych wyborów jest zatem jakoś uzasadniony. Każdy jednak niesie ze sobą nieuchronne ryzyko epistemologicznej redukcji, a więc niedostrzegania lub niedoceniania różnic i napięcia między religią a polityką.

W odniesieniu do traktowania instytucji religijnych jako swoistych „grup interesu”, czy przedstawicieli „społeczeństwa obywatelskiego” na problem ten zwraca uwagę między innymi Aniela Dylus, podkreślając potrzebę, ,,indeterministycznego" wyjaśniania publicznego statusu aktorów religijnych i przestrzegając - w tym kontekście - przed pokusą „redukcji społecznej kompleksowości do interesów”, czy też tworzenia „deterministycznego modelu społeczeństwa” [Dylus 2005: 172; 2016: 415-434]. W kontekście epistemologicznego sytuowania instytucji religijnych w tzw. III sektorze i traktowania ich jako instytucji społecznych, wskazany tu teoretyczny problem przywołuje między innymi Tadeusz Kamiński. I choć w swych bardzo interesujących studiach na ten temat pokazuje dużo dobrych racji by taki epistemologiczny zabieg akceptować, jednocześnie przywołuje związane z wyborem takim pytania i wątpliwości [Kamiński 2012]. W odniesieniu wreszcie do epistemologicznego kwalifikowania Kościołów jako aktorów sfery publicznej na problem ten zwracał uwagę piszący te słowa [Sowiński 2018] Szerzej wątku tego tu nie rozwijając zauważmy jedynie, że taki rodzaj epistemologicznego podstawienia, przy wszystkich jego zaletach, niesie ze sobą niebezpieczeństwo redukcji teologicznej nauki Kościoła (o grzechu przebaczeniu i odkupieniu, chrześcijańskim

12 Przykładów takiego rodzaju podstawienia poszukiwać można w analizach (w mojej ocenie zdecydowanie bardziej publicystycznych niż politologicznych) krytyków zaangażowania Kościoła katolickiego w sferze publicznej wolnej Polski po roku 1989, dopatrujących się w różnych przejawach tego zaangażowania walki o władzę. 
miłosierdziu) do wymiaru jedynie moralnego. Rodzi też pokusę ulegania temu co Habermas nazywa „racjonalnością deliberatywną” [tamże: 47-53]. A także, stwarza problemy wynikające $\mathrm{z}$ konieczności translacji języka religijnego na zrozumiały przez wszystkich uczestników sfery publicznej język świecki [tamże].

W efekcie powiedzieć więc możemy, że taki - sytuujący Kościół w sferze publicznej - zabieg epistemologiczny, odsłaniając wiele, nie odsłania jednak wszystkich religijnych racji Kościoła w ważnych społecznie sprawach takich jak choćby: spór o lustrację duchowych w Polsce po roku 1989, dyskusja o prawnej ochronie niedzieli, czy debata o możliwości politycznego pojednania i przebaczenia. Dlatego też, w takim funkcjonalistycznym ujęciu analitycznym, zdecydowanie bardziej uzasadnione wydaje się pytanie o rolę Kościoła w sferze publicznej, niż traktowanie go jako jeszcze jednego jej typowego aktora [tamże].

\section{Funkcjonalizm, instytucjonalizm, ujęcie historyczne (oraz ich ograniczenia) w badaniach nad religią i polityką}

Epistemologiczny i teoretyczny problem o których tu mówimy ma w naukach o polityce wymiar dość uniwersalny i zderzyć się z nim musi każdy właściwie politolog próbujący iść ową - wspomnianą wyżej - wąską ścieżką pomiędzy respektem dla religijnej tożsamości Kościołów, a wiernością swemu naukowemu warsztatowi. Mówiąc to można jednak zauważyć, że problem ów z różnym natężeniem, $\mathrm{z}$ różnymi konsekwencjami, a w każdym razie w różny sposób, daje o sobie znać na gruncie różnych podejść teoretycznych, jakie zwykli przyjmować politologowie badający politykę i religię.

Bliższej spróbujmy rozważyć to na gruncie trzech wybranych i często (choć nie wyłącznie) w badaniach nad religią i polityką praktykowanych ujęć: funkcjonalizmu, instytucjonalizmu i podejścia historycznego.

Wywodzące się z socjologii czy też etnografii podejście funkcjonalistyczne [Beyme 2005: 108] w politologicznych badaniach nad religią i polityką stosowane bywa relatywnie często, na przykład wśród badaczy wkładu Kościoła katolickiego $\mathrm{w}$ procesy integracji europejskiej, w transformacje ustrojowe, czy w demokratyzację współczesnego świata. W centrum jego teoretycznej perspektywy tkwi jak wiadomo pytanie o funkcję badanego elementu w całym badanym układzie czy systemie. I choć na gruncie nauk o polityce przywoływane jest ono czasem w sensie szerszym (largo), w formie metafory „politycznego teatru” (politycznej sceny, kulis, aktorów, publiczności etc.), to jednak częściej chyba występuje 
w sensie węższym (stricte), niosąc ze sobą pytanie o funkcjonalność (lub dysfunkcjonalność) poszczególnych elementów w stosunku do całego systemu czy procesu politycznego, a więc o to, czy poszczególne elementy i ich zachowania są zgodne $\mathrm{z}$ celami całego systemu bądź procesu politycznego [tamże: 111].

Aby jednak wydobyć interesujące nas tu napięcie między religią a polityką, tak rozumianą perspektywę funkcjonalną należy zapewne nieco poszerzyć orientując się nie tyle wobec wąsko rozumianego systemu politycznego, co wobec szerszego - korygującego politykę - systemu okołopolitycznego (czy metapolitycznego), który w rzeczywistości parlamentarnej demokracji opisywać można w kategoriach sfery publicznej, społeczeństwa obywatelskiego, III sektora, czy po prostu życia społecznego.

Ujęcie czy spojrzenie takie (zwłaszcza z zaproponowaną tu korektą), z punktu widzenia nauk o polityce, ma w interesującym nas przypadku sporo zalet. Pozwala ono na wyraźną dystynkcję między tym co publiczne a tym co polityczne, a tym samym, na uchwycenie istotnego faktu, że interesujące nas tu napięcie między religią a polityką rodzi się często w okołopolitycznej sferze publicznej, a do systemu politycznego przenika często niejako pośrednio. Tym samym, ujęcie to dobrze nadaje się na przykład do badania relacji między religią a polityką w realiach współczesnych systemów demokratycznych, w których szczególnie podkreśla się potrzebę oddzielania religii od bezpośredniego procesu politycznego.

Nie zmienia to jednak faktu, że niesie ono ze sobą możliwość, a nawet wskazaną wyżej swego rodzaju pokusę, redukcji epistemologicznej, przede wszystkim w wariancie podstawienia. Przywołując częściowe podjęte już wyżej rozważania najkrócej zauważyć bowiem możemy, że w ujęciu tym - w jakimś sensie nieuchronne - traktowanie podmiotów religijnych analogicznie jak fundacji, stowarzyszeń, instytucji edukacyjnych lub charytatywnych prowadzić może nie tylko do pominięcia religijnej tożsamości tych pierwszych, ale także, co dla nas szczególnie ważne, do zapoznania ich krytycznej lub korygującej roli. Mówiąc innymi słowy, podejście funkcjonalne, niejako siłą rzeczy jako kryterium analizy aktywności Kościół w sferze publicznej (a pośrednio jej wpływu na proces polityczny) preferuje logikę, i aksjologię tej sfery, utrudniając tym samym uchwycenie krytycznej i korekcyjnej roli Kościołów wobec samej sfery publicznej.

By posłużyć się przykładem. W aksjologię demokratycznej sfery publicznej, która kontrolować i korygować ma demokratyczny proces polityczny, obok transparencji, 
wolności czy sprawiedliwości, wpisane są wartości, które Charles Taylor określa mianem świeckości, apolityczności i metatematyczności [Taylor 1996], lub to co Habermas rozpoznaje jako - wspomnianą wyżej - „racjonalność deliberatywną" ${ }^{\text {”13 }}$. Każda z tych wartości ma swoje filozoficzne i polityczne uzasadnienie, ale każda niesie też pytania i rodzi debaty, których uczestnikiem są również Kościoły.

Korygującym i krytycznym wobec sfery publicznej (a pośrednio i politycznej) wkładem Kościołów do takich debat może być przypominanie: o ułomności ale i godności człowieka w kontekście debaty o jawności i transparencji, o potrzebie odpowiedzialności w kontekście dyskusji o wolności, o miłosierdziu w kontekście sporu o sprawiedliwość, o ludzkim głodzie transcendencji przy okazji debat o świeckości, czy o wartości jaką jest prawda obiektywna wobec presji „racjonalności deliberatywnej”. Rzecz jednak w tym, że ten krytyczny i korygujący wkład łatwo zlekceważyć czy pominąć, oceniając go - co w tym wypadku spojrzenie funkcjonalne zdaje się preferować - w światle zasad, które mają być krytycznie oceniane lub korygowane.

W tym właśnie sensie powtórzyć też możemy, że perspektywa funkcjonalna niezbyt jednoznacznie odsłania - istotną dla napięcia między religią a polityka dystynkcję między pełnieniem przez Kościół w demokratycznej sferze publicznej pewnych ról a stawaniem się przez Kościół jej typowym aktorem [Sowiński 2018: 47-53].

Podejście instytucjonalne w interesujących nas tu badaniach nad religią i polityką stosowane bywa również relatywnie często, zwłaszcza przez badaczy koncentrujących się na kształcie relacji między państwem a Kościołem (lub Kościołami).

Także i ono rozumiane może być szeroko lub wąsko, w zależności od definiowania - kluczowego tu - pojęcia instytucjonalizacji życia politycznego. W sensie szerokim (largo) instytucje rozumiane w nim być mogą ,jako czasowo, rzeczowo

${ }^{13}$ Owa forma racjonalności ma według niemieckiego filozofa charakter sieciowy i komunikacyjny, a jej źródłem są „interakcje między praworządnie zinstytucjonalizowanym kształtowaniem woli a kulturowo mobilizowanymi sferami publicznymi, które ze swej strony opierają się na zrzeszeniach społeczeństwa obywatelskiego, pozostającego w równym dystansie do państwa i do ekonomii" [Habermas 2009: 243]. Ważne wydaje się to, że choć taka forma racjonalności chroni to co Habermas nazywa „światem życia” (życie publiczne), to formy jej komunikacji „tak regulują tok dyskursywnego kształtowania opinii i woli, że jego omylne wyniki mają za sobą domniemanie rozumności” [tamże: 248]. W tym sensie Kościołom trudno zapewne bezkrytycznie przyjąć tę formę racjonalności. 
i społecznie uogólnione oczekiwania zachowań” [Beyme 2005: 90]. W sensie zaś węższym (stricte), który ma chyba częste zastosowanie w badaniach religii i polityki, rozumienie instytucji sprowadza się na ogół do kluczowych z politycznego punktu widzenia instytucji formalno-prawnych (parlament, rząd, partie polityczne, instytucje sądownicze, media), lub po prostu koncentruje się na instytucji państwa, gdyż na tym gruncie, to państwo traktowane jest - jak zauważa Klaus von Beyme - „ze szczególną czcią jako instytucja nad instytucjami” [tamże].

Takie instytucjonalne spojrzenie na relacje między religią a polityką, które tu nabierają najczęściej charakteru relacji między państwem a Kościołem, w sensie epistemologicznym wydaje się mieć szereg zalet. Po pierwsze, i dla nas chyba najważniejsze, koncentrując się często na formalnych relacjach obu instytucji, odsłania ono nie tylko pewną ograniczoną zbieżność ich celów (np. wolność religijna), ale także nieusuwalne między nimi różnice, a więc stan, który określiliśmy tu mianem napięcia. Wydaje się zatem, że właśnie w tym ujęciu dobrze widać przestroge przed sakralizowaniem instytucji politycznych, którą formułował w swoim czasie Józef Tischner. Przypominał on: „Idea Boga jest ideą tego, co absolutne. Państwo, rząd i stanowione prawo są tym, co relatywne. Gdy idea tego, co absolutne, zawiera błąd, błędne okazują się również pozostałe pojęcia. Wtedy wartości relatywne zostają podniesione do rzędu wartości absolutnych, a wartości absolutne znikają. Na tym bowiem polega błąd w myśleniu o tym, co absolutne, że absolutyzacji podlegają wartości względne. Bogiem staje się bóstwo" [cyt za: Makowski 2006]. Po wtóre, właśnie to podejście pozwala odsłonić jak z historii intrygującego procesu współpracy (ale i rywalizacji) instytucji państwa i Kościoła - od sporu o inwestyturę w X w., przez oddzielanie się myśli politycznej od religijnej i zasad pokoju Augsburskiego w wieku w wieku XVI, po współczesne procesy sekularyzacji polityki - wyłania się idea nowożytnego państwa [Böeckenförde 1994: 120; Starck 1997: 79-80]14. Po trzecie, zaletą tego instytucjonalnego podejścia wydaje się też naturalnie weń wpisana możliwość i skłonność do komparatystyki, a więc porównywania i typologizowania różnych praktykowanych modeli w relacjach państwo Kościól. A to z kolei, stwarza możliwość tworzenia swoistej

${ }^{14}$ Warto też przypomnieć myśl C. Schmitta według którego, pojęcie suwerenności, w pewnym sensie nabierać może sensu wręcz sakralnego. Odwołując się do „Lewiatana” pisał niemiecki filozof; „Gisbert Beyerhaus i Karl Theodor Budderberg wykazali, że w pojęciu suwerenności, które obowiązuje w nowoczesnym państwie prawa, zawiera się w zsekularyzowanej postaci Kalwińskie pojęcie Boga razem z charakterystyczną dlań zasadą „legibus solutus” [niezwiązany prawami]. Najwybitniejszy angielski znawca tej epoki wojen religijnych i czasu kształtowania pojęć John Neville twierdzi nawet, iż Bóg kalwinizmu to Hobbesowski Lewiatan o wszechmocy nieograniczonej przez prawo i sumienie" [Schmitt 2008: 43]. 
skali do mierzenia intensywności interesującego nas tu napięcia. Po czwarte wreszcie, w ujęciu tym badać też można relacje wobec religii (czy Kościołów) nie tylko państwa, ale także innych instytucji politycznych, takich jak choć partie polityczne $^{15}$, także i tu tworząc porównania i typologie.

Wszakże jednak i to podejście wydaje się nie być wolne od sygnalizowanej przez nas pokusy czy też tendencji do redukcji czy też zapoznawania napięcia między religią a polityką. W wariancie, który określiliśmy mianem redukcji epistemologicznej przez separację pokusa owa polegać może na zapoznawaniu faktycznego publicznego (i pośrednio politycznego) znaczenia religii w badaniach wszystkich tych przypadków, w których, $\mathrm{z}$ różnych powodów, faktycznie oddziałujące na życie społeczne (wszystkie bądź niektóre) wyznania religijne, nie są wystarczająco zinstytucjonalizowane, a reprezentujące je Kościoły lub związki religijne, nie mając statusu prawno-publicznego formalnie nie są instytucjonalnymi partnerami państwa. W tym właśnie sensie, w ujęciu czysto instytucjonalnym trudno na przykład w pełni pokazać szczególne napięcie między religią a polityką w PRL, które i dla relacji państwo - Kościół i dla funkcjonowania samego autorytarnego państwa miało przecież znaczenie zupełnie zasadnicze.

W wariancie redukcji epistemologicznej przez podstawienie, opisywane tu zagrożenie polegać może na zredukowaniu całości relacji między religią a polityką (państwem a Kościołami) wyłącznie do wymiaru formalno - prawnego, z kluczowym w takim ujęciu pytaniem, o legalność tych lub innych działań. Wtedy jednak, bardzo łatwo z badawczego pola widzenia stracić można szereg, na ogół dynamicznych, procesów kulturowych, społecznych czy politycznych, które zachodzą nieustanie w obszarze pomiędzy tym co polityczne i tym co religijne. Wtedy też, łatwo przeoczyć narastanie lub słabnięcie interesującego nas tu napięcia. Wtedy wreszcie, koncentrując się na prawno-formalnej legalności, znacznie trudniej uchwycić kluczową dla nauk o polityce kwestię legitymizacji religii i polityki w ich wzajemnym odniesieniu.

Mówiąc jeszcze innymi słowy, podejście instytucjonalne w badaniach relacji między religią a polityką, koncentrując się na procedurach, które relacje te mają w taki lub inny sposób porządkować, regulować lub standaryzować, siłą rzeczy gubić może perspektywę odmienności, sporu i konfliktu. Perspektywę, która jest wszakże immanentną częścią interesującego nas w tym opracowaniu napięcia.

${ }^{15}$ Ciekawy przykład takich badań w polskiej literaturze prezentuje m.in. prof. Krzysztof Kowalczyk [2012]. 
Na koniec, w interesującej nas tu perspektywie, przywołajmy jeszcze po krótce stosowane w naukach o polityce podejście historyczne, zwane także historyczno-genetycznym. Jego istotą jest jak wiadomo koncentrowanie się na politycznej temporalności i politycznej zmianie, co w konsekwencji prowadzi często do rozmaitych periodyzacji w opisie procesu politycznego, rekonstruowania jego poszczególnych sekwencji, prób wskazania momentów przełomowych, czy budowania wyjaśnień przyczyno - skutkowych [Beyme 2005: 80nn].

Pozostawiając na boku interesujący skądinąd problem metodologicznych relacji tego politologicznego podejścia wobec nauk historycznych, zauważmy jedynie, że także ono w obszarze badań na religią i polityką stosowane bywa stosunkowo często, zwłaszcza w monografiach usiłujących uchwyć dynamikę zmian w obrębie jednego państwa, czy systemu politycznego [Deląg 2016]. I podobnie jak w przypadku funkcjonalizmu czy podejścia instytucjonalnego, ma ono - w interesującym nas tu kontekście - swoje zalety i ograniczenia.

Wśród zalet wskazać można przede wszystkim pewnego rodzaju metodologiczną otwartość, która koncentrując się na temporalności badanego procesu bądź stanu politycznego pozostawia badaczowi wolną rękę w wyborze aspektu zmieniającej się rzeczywistości, który ma być badany. W tym senesie, w ujęciu tym, to od wiedzy, doświadczeń i metodologicznej wyobraźni badacza zależy takie zaprojektowanie badań i takie zdefiniowanie ich bezpośredniego przedmiotu, które interesujące nas tu napięcie między religią a polityką odsłonić może najpełniej. Po wtóre, warto też zauważyć, że podejście historyczne, jak bodaj żadne inne pozwala uchwycić, często w naukach o polityce podejmowaną, fundamentalną kwestię politycznej trwałości lub politycznej zmiany. Dzięki temu właśnie, na gruncie tego podejścia podejmować się możemy nie banalnego rozstrzygnięcia, czy napięcie między religią a polityką jest stanem naturalnym, do którego każdy system polityczny zmierza niejako siłą własnej inercji, i który można jedynie łagodzić lub odsuwać w czasie? Czy też - jak sugerowaliśmy wyżej - jest zgoła odwrotnie, a stanem naturalnym, który można jednie korygować, łagodzić lub odsuwać w czasie jest (występujące po stronie religii, polityki, lub po stronie obu tych fenomenów) dążenie redukcji tego napięcia, przez separację lub utożsamianie?

Wśród interesujących nas tu ograniczeń i skłonności do epistemologicznej redukcji wskazać możemy natomiast, po pierwsze, pojawiającą się tu możliwość pewnej - tak to określiliśmy - redukcji aksjologicznej. Chodzi mówiąc krótko o to, że badacze dziejów określonego społecznego czy politycznego bytu, świadomie lub 
nie, dokonują czasem pewnego wyboru metodologicznego, koncentrując się albo nad wymiarem trwałości i trwania, albo nad tendencjami do zmiany. Czasem też, taki wybór metodologiczny przyjmuje kształt zgoła aksjologiczny, albo w postaci paradygmatu tradycyjnego, gdzie wypowiedzianą lub niewypowiedzianą wartością staje się sama trwałość określonych zachowań, przekonań czy instytucji, albo w postaci paradygmatu modernistycznego, gdy wartością staje się sama zmiana, bardzo często kojarzona w oświeceniową ideą nowoczesności i postępu. Taka tradycyjna lub modernistyczna skłonność epistemologiczna, w badaniach relacji między religią o polityką, przesłaniać może obraz zarówno jednego jak i drugiego fenomenu, jak i obraz rzeczywistej relacji między nimi.

Po wtóre, w odniesieniu religii i polityki, warto też pamiętać, że w każdym z tych dwu szczególnych obszarów czas biegnie innym na ogół rytmem, następują inne momenty zwrotne, inne jest też postrzeganie samej historii. Stąd mierzenie religii i polityki jedna wspólną historyczną miarą i pokazywanie jednej wspólnej ich zmiany, albo mówiąc inaczej, wspólne wpisywanie ich w jedną, prezentowaną w badaniach czasową sekwencję, zacierać może nieco obraz rzeczywistości, wpływając też na niedostrzeganie różnic czy też napięcia między religią a polityką.

By posłużyć się dwa tylko przykładami. W badaniach nad relacjami religii i polityki we współczesnej Polsce, formułowane bywa czasem przekonanie, że ponieważ po roku 1989 (lub 2004) głębokiej transformacji uległ system polityczny i życie społeczne, podobnej transformacji ulec powinien także polski katolicyzm i obecny w polskim społeczeństwie Kościół. Brak bowiem takiej transformacji - w ujęciu tym - rodzić miałby zbędne, dysfunkcyjne konflikty między nowoczesnym społeczeństwem a „niewystarczająco nowoczesnym Kościołem”. Wydaje się, że takie spojrzenie, wynikające właśnie z oczekiwania zbieżności kierunku i tempa zmian w świecie religii i polityki, zamazuje istotę relacji między religią a polityką.

Przykład drugi. Zauważmy, że fundamentalne zmiany jakie zaszły w Kościele katolickim na skutek Soboru Watykańskiego II (1962 - 1965) dość powszechnie, w demokratycznej opinii publicznej uznawane są na przejaw pewnego uwspółcześnienia Kościoła, a w każdym razie jego aggiornamento czyli otwarcia na otaczający świat. Rzecz jednak w tym, że w teologicznej logice, którą kierowali się Ojcowie Soborowi mówi się nie tyle (czy nie tylko) o uwspółcześnieniu chrześcijaństwa, ale przede wszystkim o jego powrocie do ewangelicznych źródeł, a więc czymś co w progresywnej i linearnej logice współczesnej polityki trudno zrozumieć. 
Zauważmy wreszcie po trzecie, że przywołane tu przez nas podejście historyczne, w badaniach relacji między religią, koncentrując się na ewentualnej różnorodności tych relacji w zachodzącej w czasie (zmianach lub braku zmian) mniej siłą rzeczy miejsca pozostawia na uchwycenie wewnętrznych zróżnicowań w świecie religii i w świecie polityki, które w istotny sposób wpływać mogą na interesujące nas napięcie.

Wnioski. W kierunku systemu zdań ideologicznie i metodologicznie otwartych ${ }^{16}$ Szukając pointy i podsumowania dla naszych rozważań trudno jak się wydaje wskazać proste rozwiązanie swego rodzaju epistemologicznej kwadratury koła jaką jest badanie relacji między polityką a religią, na teoretycznym gruncie nauk o polityce. Nie znaczy to jednak, i do takiego wniosku prowadzić mogą nasze rozważania, że nie da się tego metodologicznego problemu nieco zniwelować, uwrażliwiając nieco nauki o polityce na „niepolityczną polityczność religii”.

Mówiąc najkrócej i najogólniej powiedzieć zatem możemy, że badania relacji religii z polityką, aby nie gubić ze swego horyzontu poznawczego sygnalizowanego przez nas unikalnego napięcia, pozostawać powinny przede wszystkim, przy całej ich naukowej tożsamości, systemem zdań ideologicznie oraz metodologicznie otwartych.

Otwartość ideologiczna oznacza tu unikanie wszelkich paradygmatów wartościujących apriorycznie religijne rozumienie świata, czy odrzucających możliwość jego racjonalnej analizy ze względu na aktualne możliwości poznawcze. Chodzi tu mówiąc krótko przede wszystkim o unikanie deterministycznej wersji paradygmatu sekularyzacyjnego, na rzecz tego co Margaret Archer i pokrewni jej badacze nazywają „realizmem krytycznym”. Jak wyjaśnia w ciekawym opracowaniu Artur Wysocki, jest to rekomendacja przyjęcia jako paradygmatów badawczych „realizmu ontologicznego" i „relatywizmu epistemologicznego”, czyli wstępnego założenia, że byt i jego istnienie jest czymś pierwotnym wobec możliwości jego poznania [Wysocki 2015]. W podobny choć nieco bardziej filozoficzny sposób postulat taki formułuje także kard. Józef Ratzinger dedykując współczesnym „moim przyjaciołom, którzy nie wierzą" Pascalowską radę, by we wspólnej debacie o otaczającym nas świecie, oświeceniowe, wykluczające religijną świadomość, założenie etsi Deus non daretur, zastąpić pozytywnym, otwartym na możliwość istnienia Boga

${ }^{16}$ Określeniem „system zdań otwartych” w tym kontekście posługuję się za nestorem warszawskiej szkoły katolickiej nauki społecznej ks. prof. Helmutem Jurosem, który używa go właśnie w odniesieniu do KNS. 
założeniem veluti si Deus daretur. Analogicznej rekomendacji epistemologicznej otwartości o. Maciej Zięba poszukuje także w filozofii Karla Poppera, przywołując choćby następujące słowa autora koncepcji „Społeczeństwa otwartego”: „trzeba podjąć trud i ryzyko wędrowania, będąc zaopatrzonym jedynie w „antropologiczną busolę (...). 'Musimy kroczyć na przód ku temu, co nieznane, niepewne i niebezpieczne, używając rozumu za przewodnika ku obojgu - ku bezpieczeństwu i wolności” [Zięba 2011: 145]. Jej ślady wskazać także można w myśli Jürgena Habermasa [Teinert 2006: 163-164].

W interesującym nas przypadku nauk o polityce, które badać chcą religię i politykę, taka postawa badawcza oznaczać powinna przyjęcie możliwości istnienia Boga, czy prawdziwości religijnego obrazu świata, niezależnie od tego czy przy pomocy dostępnych dziś narzędzi badawczych, jesteśmy to w stanie zweryfikować.

Otwartość zaś metodologiczna jaką rozważaniami naszymi chcemy rekomendować oznacza teoretyczny wysiłek w poszukiwaniu wąskiej i trudnej zapewne do odkrycia oraz przebycia, epistemologicznej ścieżki, która pozostając na gruncie nauk o polityce, doprowadzić ma do punktu widzenia, z którego - do końca niepoznawalną narzędziami politologicznymi - religię i jej iskrzenie z polityką, widać najlepiej.

Próbując tę ogólną rekomendację nieco rozwinąć, po pierwsze zauważyć możemy, że choć ścieżki takie - jak wspomnieliśmy na wstępie - już istnieją, trud odkrycia wystarczającej ich ilości, jest ciągle przed naukami o polityce. Zwłaszcza, że wiele z nich jest wyborem oryginalnym, niepowtarzalnym, adekwatnym głównie w obszarze i sytuacji badawczej, w której powstały.

Po drugie z badań naszych wynika jak się wydaje ostrożna metodologiczna konstatacja, że istotne znaczenie w projektowaniu badań religii i polityki ma świadomy wybór podejścia teoretycznego. Z przywołanych przez nas przykładowo trzech podejść (funkcjonalizmu, instytucjonalizmu i podejścia historycznego) ostrożnie zauważyć można, że w aspekcie wskazywanego przez nas napięcia między religią a polityką najbardziej epistemologicznie otwarte wydaje się podejście historycznie. Niemniej jednak, rekomendacją znacznie pewniejszą jaka w tym zakresie wynika z naszych rozważań wydaje się postulat metodologicznej dywersyfikacji, czyli w pełni uświadomionego i przemyślanego uzupełniania wybranego (wiodącego) horyzontu badawczego o inne horyzonty, dzięki czemu na badany aspekt relacji między religią i polityką spojrzeć można z różnych politologicznych perspektyw, wzajem perspektywy te weryfikując i uzupełniając. 
Po trzecie wreszcie, wynika z tego szersza jeszcze rekomendacja metateoretyczna, zgodnie z którą, o intrygującej relacji religii i polityki znacznie więcej do powiedzenia niż wąsko rozumiana politologia mają szerzej rozumiane nauki o polityce. Wątku tego nie rozwijając i pozostawiając na boku bardzo ciekawą dysputę metateoretyczną na temat przydatności i ułomności każdej z tych koncepcji badań polityki, tu zauważmy tylko, że w dostrzeżeniu wpływu religii na politykę wąsko rozumianej politologii pomóc mogą także inne nauki, takie jak historia, socjologia, psychologia czy teologia. Dlatego, analogicznie jak w katolickiej nauce społecznej, która swą metodologiczną konstrukcję opiera o kilka dyscyplin naukowych, np. socjologię, ekonomię etykę czy teologię, także w badaniach dotyczących polityki i religii znacznie efektywniejsza wydaje się metateortyczna formuła nauk o polityce, która otwiera na uporządkowane i przemyślane korzystanie z różnych metod i punktów widzenia, od zawężającej perspektywę badawczą formuły politologia.

Rozważania nasze rozpoczęliśmy od przywołania myśli prof. Ernsta-Wolfganga Böckenfördego. Zakończmy je następującą konstatacją. Słynny - wspomniany na wstępie - „paradygmat Böckenfördego” dotyczy jak się wydaje nie tylko przedmiotu badań jakim jest religia i polityka, ale niesie ze sobą także istotną przesłankę metodologiczną. Parafrazując zaś myśl wybitnego badacza sformułować ją możemy tak: nauki o polityce, w badaniach nad religią i polityką mogą zachować swój potencjał badawczy pod warunkiem ich ideowej i metodologicznej otwartości na rzeczywistość religijną, której dokładnie poznać i wyjaśnić same nie mogą.

\section{Bibliografia}

Acton J. (1995), Historia wolności. Wybór esejów, przekł. A. Branny, A. Gowin, P. Śpiewak, Wydawnictwo Znak, Kraków.

Basdevant-Gaudemet B. (2007), Państwo i kościół we Francji, [w:] G. Robbers (red.), Państwo i kościót w krajach Unii Europejskiej, Robbers G. (red.), Państwo i Kościót w krajach Unii Europejskiej, przekł. J. Łopatowska - Rynkowska, M. Rynkowski, Kolonia Limited, Wrocław. s. 123-146.

Berger P.L. (1997), Święty baldachim. Elementy socjologicznej teorii religii, przekł. W Kurdziel, Zakład Wydawniczy NOMOS, Kraków.

Beyme von K. (2005), Wspótczesne teorie polityczne, przekł. J. Łoziński, Wydawnictwo Naukowe Scholar, Warszawa.

Böckenförde E. W. (1994), Wolność-państwo-Kościót, przekł. P. Kaczorowski, Wydawnictwo Znak, Kraków. 
Borowik I. (1997), Socjologia religii Petera L. Bergera, w: P.L. Berger, Święty baldachim. Elementy socjologicznej teorii religii, przekł. W Kurdziel, Zakład Wydawniczy NOMOS, Kraków, s. 7-24.

BP KEP (2018), Przewodniczacy KEP: Stabilna przyszłość naszej Ojczyzny zależy najpierw od odnowy naszej wiary (dokumentacja, Katolicka Agencja Informacyjna, Warszawa 11 listopada 2018).

Burgoński P. (2013), Model obecności i naturalnego napięcia, [w]: S. Sowiński (red.), Obecność Kościoła katolickiego w sferze publicznej demokratycznego państwa prawa. Przykład współczesnej Polski, Instytut Politologii UKSW, Warszawa.

Casanova J. (2005), Religie publiczne w nowoczesnym świecie, przekł. Kunz T., Zakład Wydawniczy NOMOS, Kraków.

Deląg M. (2016), Konferencja Episkopatu Polski wobec wybranych kwestii politycznych ispołecznych w Polsce w latach 1989-2014, Wydawnictwo Uniwersytetu Rzeszowskiego, Rzeszów.

Dylus A. (2005), Globalizacja. Refleksje etyczne, Ossolineum, Wrocław.

Dylus A. (2016), Polityka w perspektywie etycznej i religijnej, Wydawnictwo Naukowe UKSW, Warszawa.

Gierycz M. (2009), Przejawy instrumentalizacji religii w polityce, [w:] P. Burgoński, S. Sowiński (red.), Ile Kościoła w polityce, ile polityki w Kościele, Wydawnictwo Księgarnia św. Jacka, Katowice, s. 179-204.

Grosfeld J. (2009), Kilka uwag o instrumentalizacji religii, [w:] P. Burgoński, S. Sowiński (red.), Ile Kościoła w polityce, ile polityki w Kościele, Wydawnictwo Księgarnia św. Jacka, Katowice, s. 211-222.

Habermas J. (2009), Uwzględniajac innego. Studia do teorii politycznej, przekł. A. Romaniuk, Wydawnictwo Naukowe PWN, Warszawa.

Höffner J. (1999), Chrześcijańska nauka społeczna, przekł. J. Bokwa, Wydawnictwo Fundacji ATK, Warszawa.

Kamiński T. (2012), Caritas i polityka. Podmioty wyznaniowe w systemie polityki społecznej, Wydawnictwo UKSW, Warszawa.

Kołakowski L. (1990), Cywilizacja na ławie oskarżonych i inne eseje, Res Publica, Warszawa 1990.

Konstytucja duszpasterska o Kościele w świece współczesnym, [w:] Sobór Watykański II. Konstytucje. Dekrety. Deklaracje. Wydawnictwo Pallotinum, wyd III, Poznań.

Konstytucja Rzeczpospolitej Polskiej, Tekst uchwalony w dniu 2 kwietnia 1997 r. przez Zgromadzenie Narodowe, w: http://www.sejm.gov.pl/prawo/konst/polski/kon1.htm.

Kowalczyk K. (2012), Partie i ugrupowania parlamentarne wobec Kościoła katolickiego w Polsce w latach 1989 - 2011, Wydawnictwo ZAPOL, Szczecin.

Luckmann T. (2006), Niewidzialna religia, przekł. T. Bluszcz, Zakład Wydawniczy NOMOS, wyd. II Kraków.

Luhmann N. (2007), Funkcje religii, przekł. D. Motak, Zakład Wydawniczy NOMOS, Kraków.

Makowski J. (2006), Ten naród czci mnie wargami, [w:] „Gazeta Wyborcza”, 27 grudnia. Mazurkiewicz P. (2017), Niepolityczna polityczność Kościoła, [w]: tenże, Europa jako kinder niespodzianka, Ośrodek Myśli Politycznej, Kraków. 
Ratzinger J. (2005), Refleksje na temat kultur które są dzisiaj sobie przeciwne, przekł. W. Dzieża, [w:] tenże, Europa Benedykta w kryzysie kultur, Wydawnictwo Edycja Świętego Pawła, Częstochowa.

Robbers G. (red.) (2007), Państwo i Kościót w krajach Unii Europejskiej, przekł. J. Łopatowska - Rynkowska, M. Rynkowski, Kolonia Limited, Wrocław.

Schmitt C. (2008), Lewiatan w teorii państwa Tomasza Hobbesa. Sens i niepowodzenie politycznego symbolu, przekł. M. Falkowski, Wydawnictwo Prószyński i S-ka, Warszawa.

Sowiński S. (2012), Boskie, cesarskie, publiczne. Debata o legitymizacji Kościoła katolickiego w Polsce w sferze publicznej w latach 1989 - 2010, Oficyna Wydawnicza ASPRA JR, Warszawa.

Sowiński S. (2018), Kościót w przestrzeni publicznej. Aktor czy rola, [w:] M. Marczewska - Rytko i D. Maj (red.), Politologia religii, Wydawnictwo Uniwersytetu Marii Curie Skłodowskiej, Lublin, s. 35-53.

Starck Ch. (1997), Znaczenie chrześcijaństwa i Kościoła dla tożsamości Unii Europejskiej, [w]: H. Juros (red.) Europa i Kościót, Fundacja ATK, Warszawa 1997, s. 75 - 100.

Taylor Ch. (1996), Polityka liberalna a sfera publiczna, przekł. A. Pawelec, [w:] Społeczeństwo liberalne. Rozmowy w Castel Gandolfo, red. K. Michalski, Kraków, s. 21-47.

Teinert Z. (2006), Habermas $i$ Ratzinger: wiara $i$ wiedza $w$ dobie sekularyzacji, „Poznańskie Studia Teologiczne", t. 20.

Tocqueville de A. (1996), O demokracji w Ameryce, przekł. Janicka B., Król M., t. I i II, Społeczny Instytut Wydawniczy Znak, Kraków.

Węgrzecki J. (red.) (2016), Religia obywatelska w Polsce, Wydawnictwo UKSW, Warszawa.

Wysocki A. (2015), Transcendencja w ujęciu Margaret S. Archer, „Uniwersyteckie Czasopismo Socjologiczne" nr 10, s. 130-153.

Zenderowski R. (2011), Religia a tożsamość narodowa i nacjonalizm w Europie ŚrodkowoWschodniej. Między etnicyzacja religii a sakralizacja etosu (narodu), Wydawnictwo Uniwersytetu Wrocławskiego, Wrocław.

Zięba M. (1998), Papieże i kapitalizm. Od Rerum Novarum do Centesimus Annus, Wydawnictwo Znak, Kraków.

Zięba M. (2011), Nieznane, niepewne, niebezpieczne? Szkice o Europie, Wydawnictwo PIW, Warszawa. 